\title{
Effectiveness of Shame Management Training Program on Aggression and Social Skills of Children with Hearing Impairment
}

\author{
Baqer Hasanvand ${ }^{1}$, Parviz Sharifi Daramadi ${ }^{* 2}$, Ali Delavar ${ }^{3}$, Parvane Alaei ${ }^{4}$ \\ 1. Ph.D. Student of Psychology and Education of Exceptional Children, Faculty of Psychology and Educational Sciences, \\ Allameh Tabataba'i University, Tehran, Iran \\ 2. Professor, Department of Psychology and Education of Exceptional Children, Faculty of Psychology and Educational Sciences, \\ Allameh Tabataba'i University, Tehran, Iran \\ 3. Professor, Department of Measurement, Faculty of Psychology and Educational Sciences, Allameh Tabataba'i University, \\ Tehran, Iran \\ 4. Assistant Professor, Department of Family Studies, University of Shahid Madani, Azarbayjan, Iran
}

Received: February 6, 2018

Accepted: July 3, 2018

\begin{abstract}
Background and Purpose: Several methods are used to increase social skills and adaptation of people with hearing impairment. In this regard, the present study aimed to determine the effectiveness of shame management training program on aggression and social skills of children with hearing impairment.

Method: This research was a semi-experimental study with pretest-posttest control group design. The statistical population consisted of all students with hearing impairment in the city of Karaj in 2017. Using a convenient sampling method, 30 of them were selected as the sample and randomly assigned to the experimental and control groups. Social skills rating scale (SSRS) and aggression questionnaire (Bass \& Warren, 2000) were used to collect data. Educational intervention was conducted for the experimental group in 14 sessions, while the control group did not receive such intervention. At the end, the data were analyzed by multivariate analysis of covariance.

Results: The findings of this study showed that shame management training program has a significant effect on reducing aggression and verbal components, anger, and hostility of aggression ,except the physical component of aggression. In addition, in the current study, the effectiveness of the shame management curriculum on social skills, the components of cooperation, selfexpression, and self-control were confirmed $(\mathrm{P}<0.01)$.

Conclusion: According to the results of this study, shame management training program, which increases the self-esteem of hearing impaired children, is an effective way to reduce aggression and to improve communication skills.
\end{abstract}

Keywords: Shame management, aggression, social skills, hearing impairment, students

Citation: Hasanvand B, Sharifi Daramadi P, Delavar A, Alaei P. Effectiveness of shame management training program on aggression and social skills of children with hearing impairment. Quarterly Journal of Child Mental Health. 2019; 6(1): 149-162.

*Corresponding author: Parviz Sharifi Daramadi, Professor, Department of Psychology and Education of Exceptional Children, Faculty of Psychology and Educational Sciences, Allameh Tabataba'i University, Tehran, Iran.

Email: Dr_sharifidaramadi@yahoo.com $\quad$ Tel: (+98) 21-48393176 


\title{
اثربخشى برنامه آموزش مديريت شرم بر يرخاشكرى و مهارتهاى اجتماعى
}

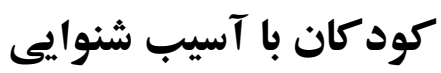

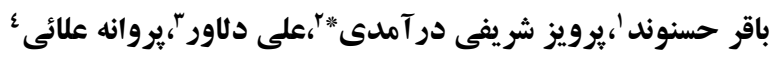 \\ 1. دانشجوى دكتراى روانشناسى و آموزش كود كان استثنايى، دانشكده روانشناسى و علوم تربيتى، دانشكاه علامه طباطبائى، تهران، ايران

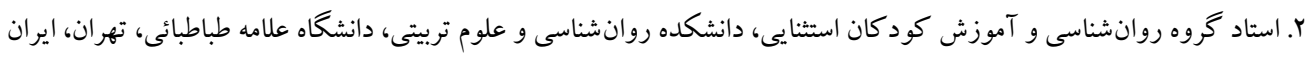

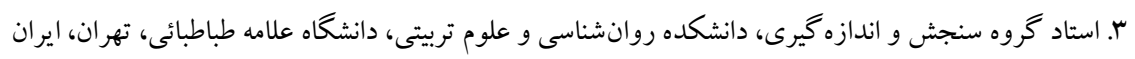

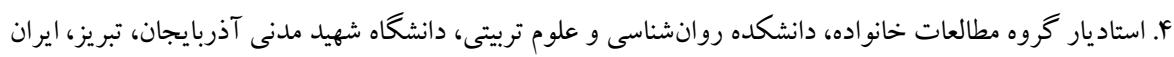

تV

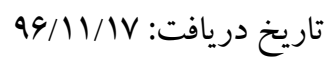

جكيده

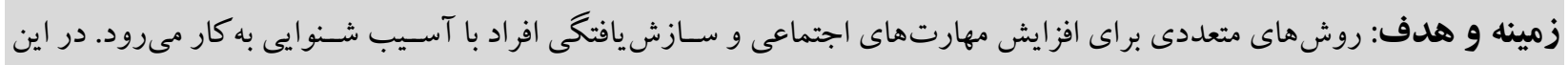

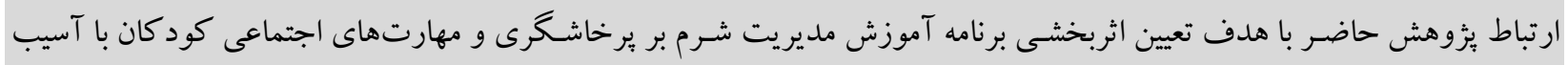
شنو ايى انجام شده است.

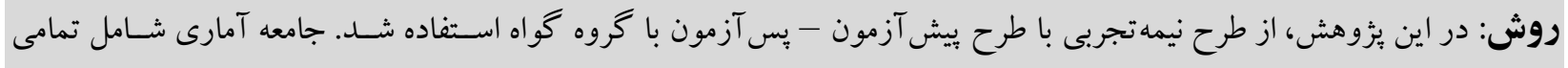

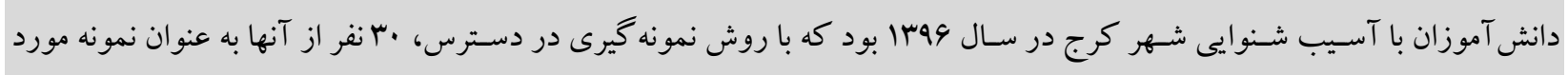

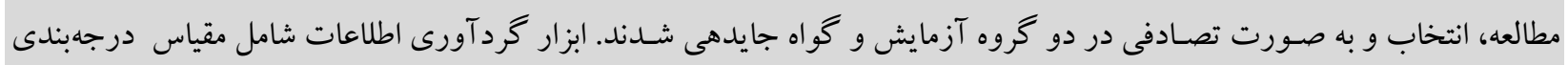

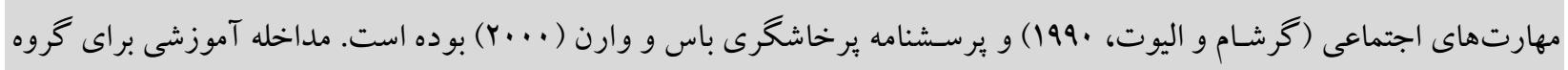

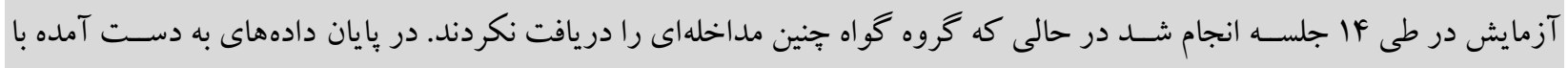
آزمون تحليل كوواريانس جندمتغيره تحليل شدند.

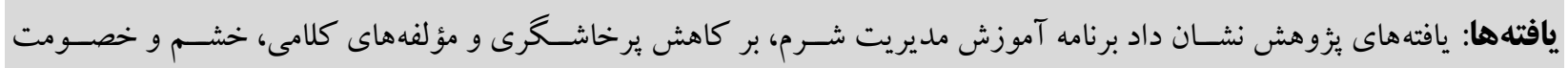

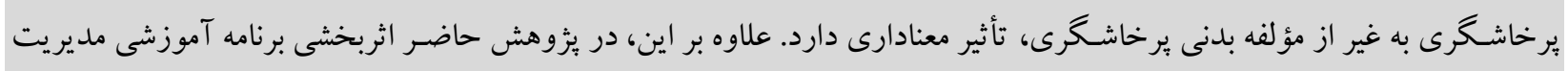

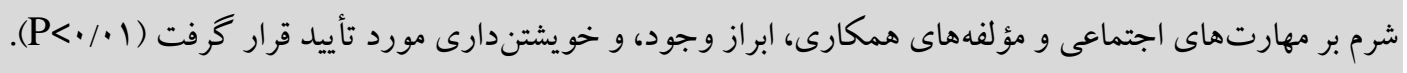

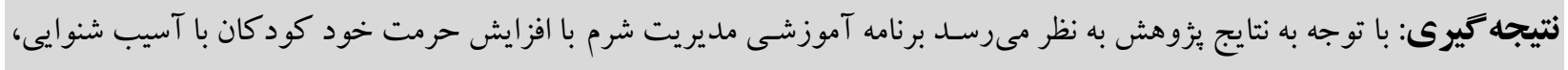

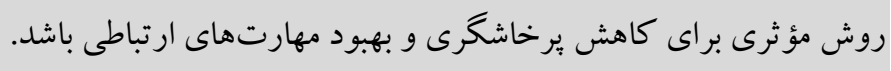
كليدوازهها: مديريت شرم، برخاشكرى، مهارتهاى اجتماعى، آسيب شنو ايى، دانشى آموزان

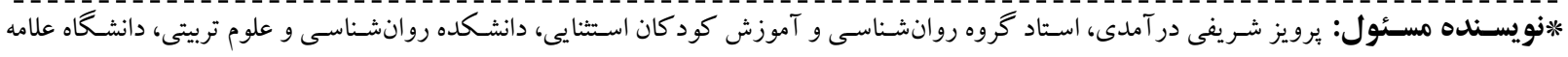
طباطبائى، تهران، ايران. تلفن: Fi - FrarIVS ايميل: Dr_sharifidaramadi@yahoo.co 
خشـونت تبديل مىشـود؛ در واقع برخاشخرى بيش زمينه بروز

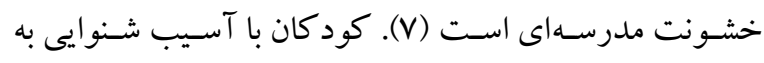
دليل نقص شـنيدارى در فضـاهاى آموزشسى مشـكلاتى از قبيل مدردهان

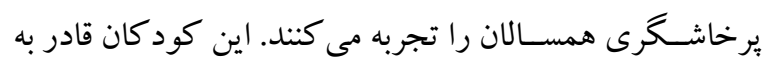
مديريت برخى رفتارهاى خود نيستند و از سويى كود كان قلدر

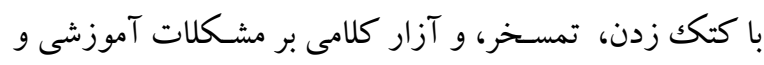

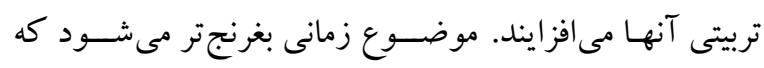

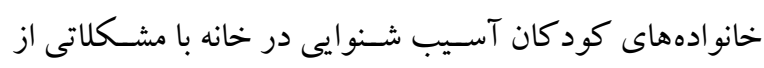

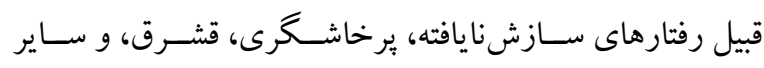
رفتارهاى دشوار مواجه مىشوند و مهار رفتارهاى آنها از اختيار

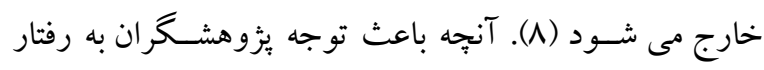

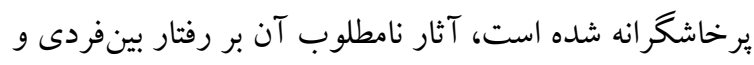

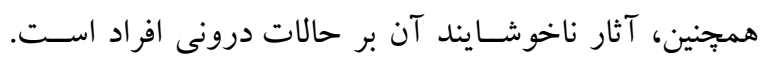

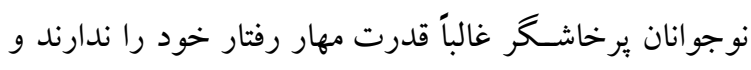

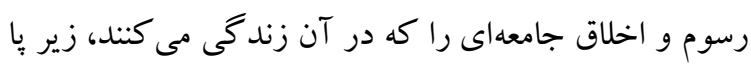
مى گذارند (9). نداشتن مهارت مديريت شرم از سويى و فقدان

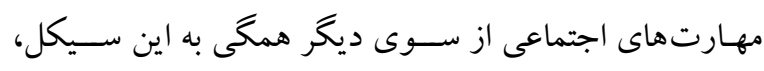

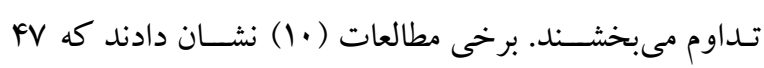

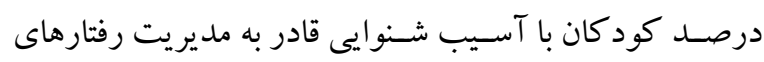
خود نيستند و فقدان مهارتهاى اجتماعى به مشكلاتى از قبيل

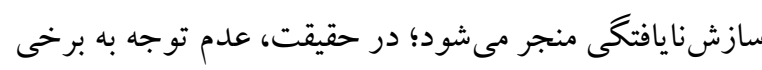

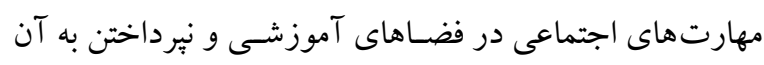

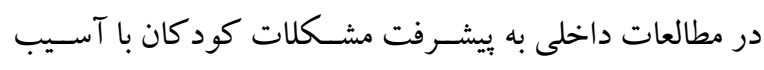

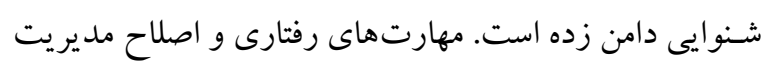

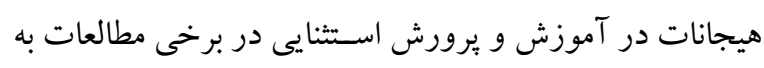

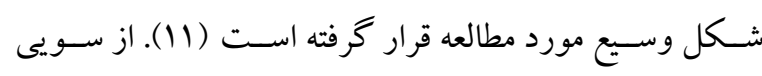

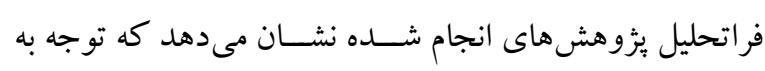
بهبود و ارتقـاى برنـامههاى مداخلهاى به خصــوص درو در محيط

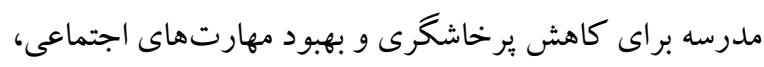

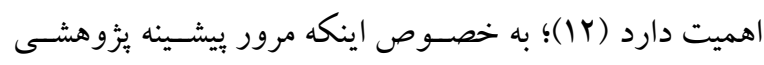

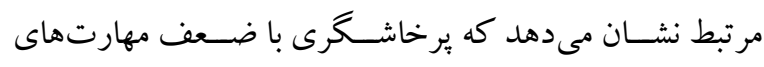

\section{مقدمه}

شخصى كه با آسيب شنوايى متولد مىشود، با جالشهاى مهم

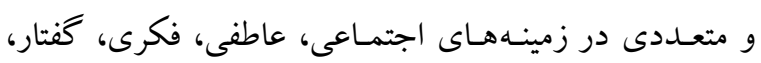

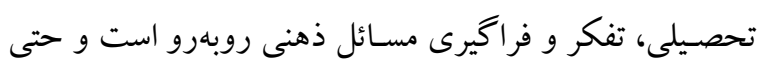

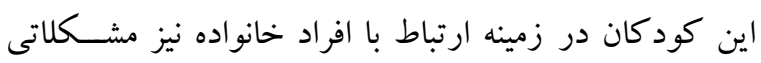
دارنــ (1). در همين راسـتـا، يكى از مشــكلـات هيجانى كه

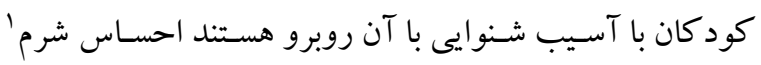

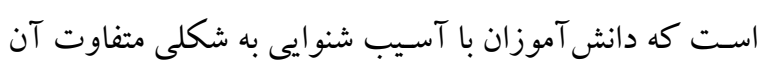

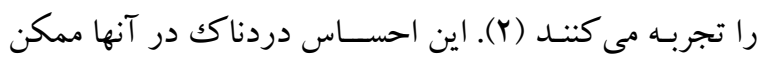
اسـت بهصسورت حالت تدافعى، خشـم و بر خاشـخرى آشـكار فراخوانى شـود و اغلب با احساس انتقامجويى و كهترى همر اه

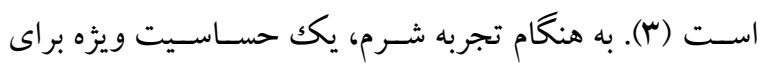

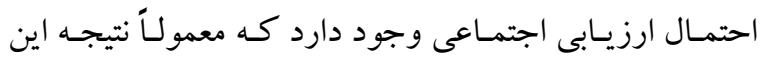

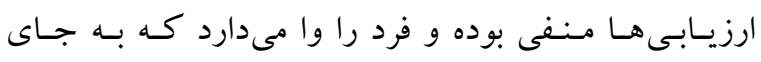

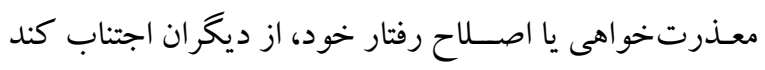

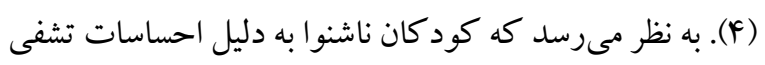

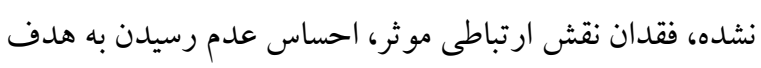
و مؤثر واقع نشدن در محيطهاى اجتماعى و بين فردى، تمايلات

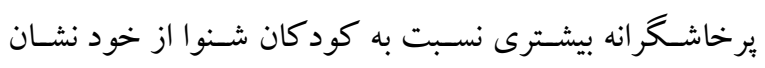

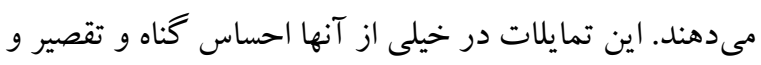
حتى خشم معطوف به خود را بهوجود مى آورد (ه).

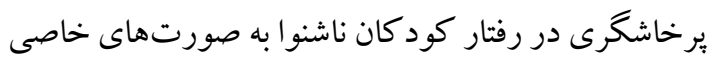

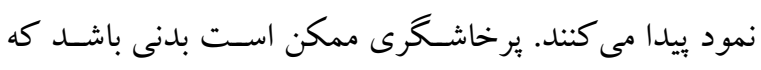

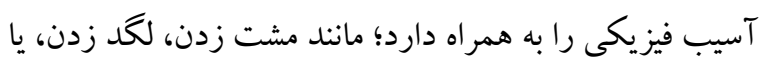

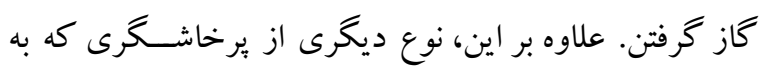

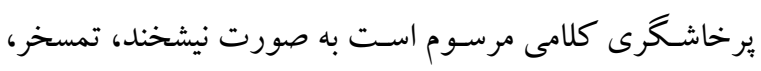

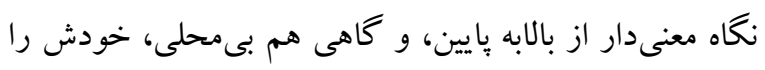

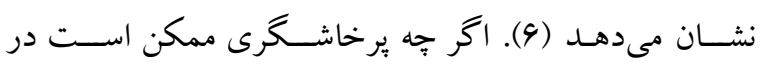
محيط هاى مختلف اتفاق بيفتد، اما آنجه كه بيشـتر مورد توجه

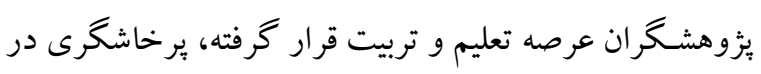

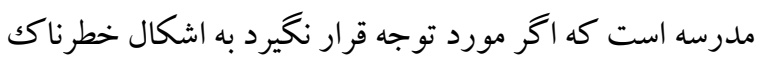

\section{Shame}


ارائـه برنـامـهـــاى آموزشــى در زمينه ســامت روانى و

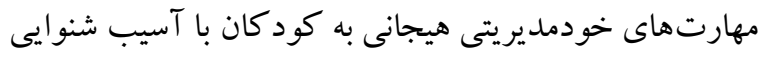
در جهـت كـاهش اثرات منفى تعـارضهـا و هيجانهاى منفى، بهـ بسـيار مهم اسـت و بنابراين توجه به بهبود و ارتقاى برنامههاى

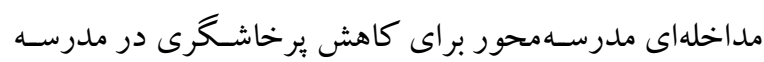

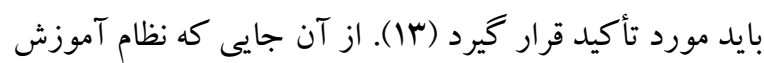
و يرورش استثنايى هزينه زيادى جهت تحول هيجانى - عاطفى

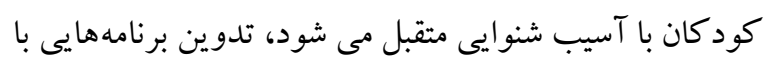

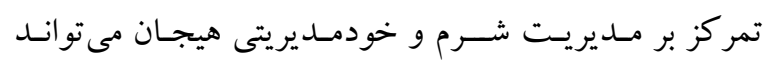

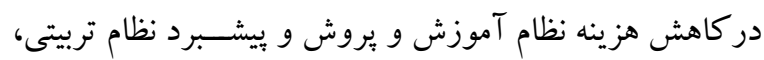

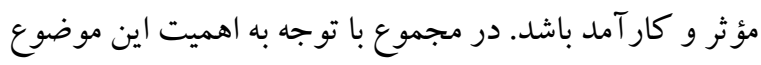

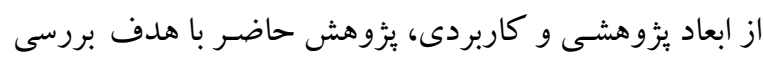

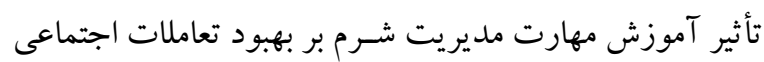
و كاهش برخاشـخرى كود كان با آسـيب شـنو ايى انجام شـده بره

\section{ووش}

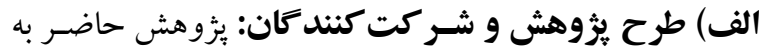

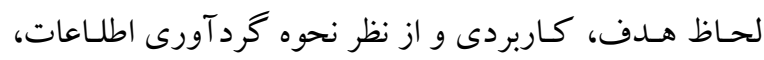

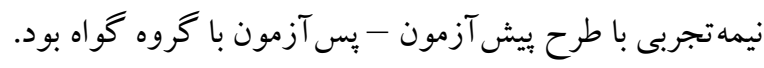

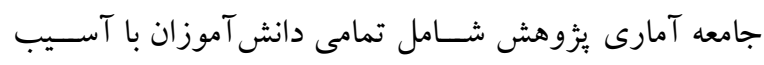

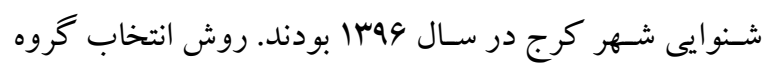

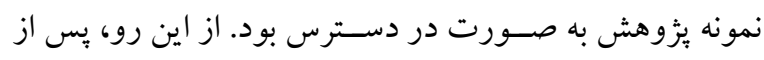

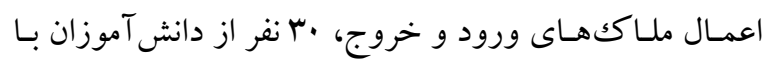

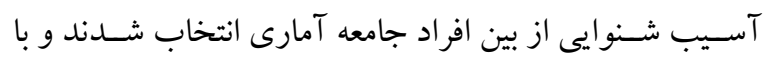

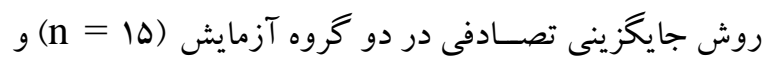

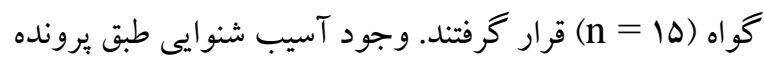
تحصيلى، تحصيل در مدارس آموزش عمومى، فقدان همبودى با ساير اختلالات ماند نابينايى، كم توانى ذهنى، ناتوانى حر كتى،

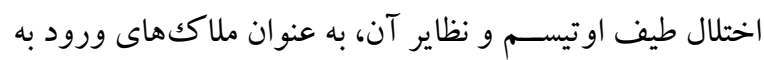

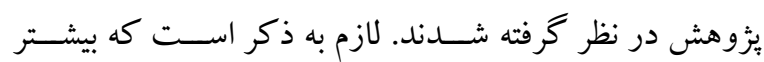

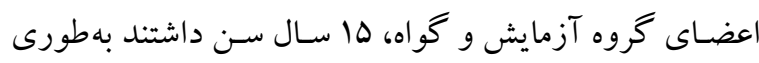

اجتماعى به ويزه مهارت حل مسئله (V) و هوش اجتماعى (r)

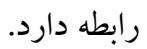

از اين رو، همواره دغدغه بسـيارى از آموزندكان اين بوده

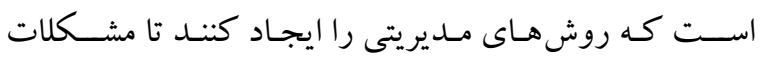

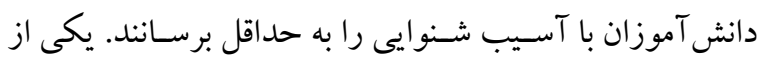
مهارتهايى كه در كود كان با آسيب شنو ايى داراى رفتارهاى

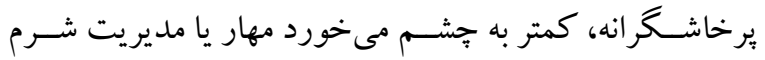

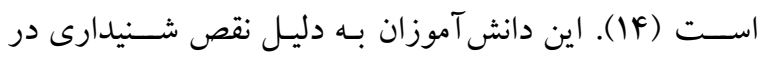

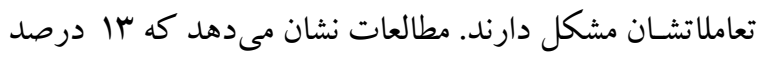

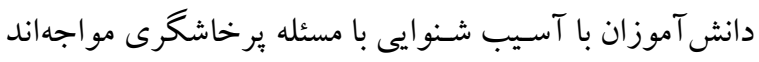

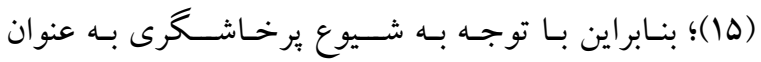

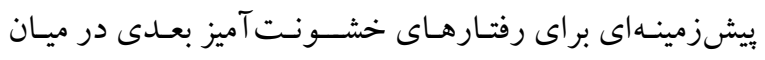

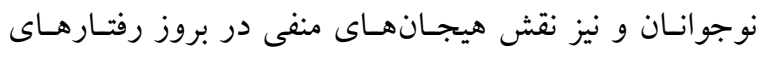

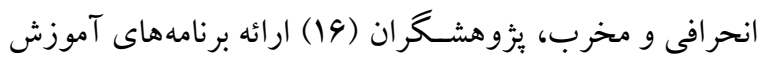
در زمينه ســامت روانى و مهارت هاى خودمدير يترونى هيجانى را

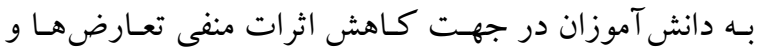
هيجان هاى منفى و در نهايت بيشـيرى از رفتارهاى ناسالم در كنار دروس شناختى مدارس، توصيه كردهاند. در نتيجه به نظر

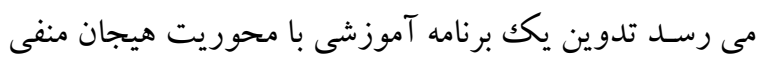

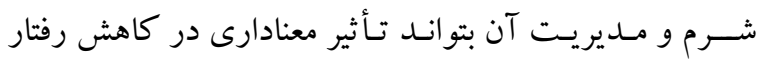

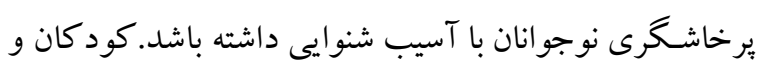

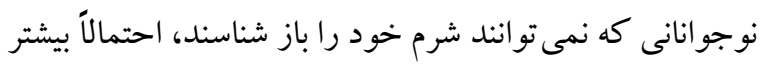

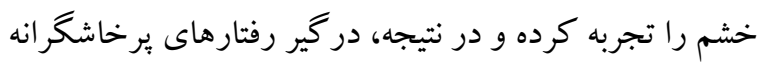

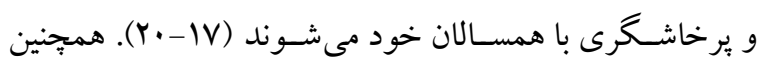
كود كان و نوجوانانى كه شـرم خود را جابجا مى كنند تمايلات تلافى جويانه قوى نسـبت به سـايرين دارند، از اين رو انتظار بر

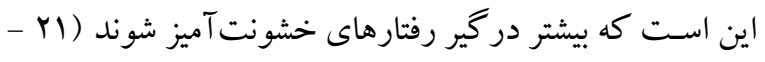

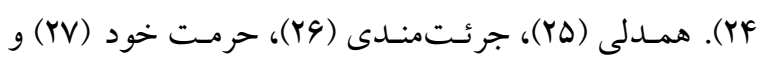
مهار خشــم (YN)، باسـخ سـازش يافته در بر ابر شرم و مؤلفههاى مديريت شـرم محسوب مى شوند كه با مهارتهاى ارتباطى نيز

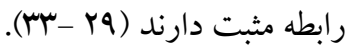


صـحيح و غلط وجود نـدارد. اين برسـشــنامه يكك وســيله

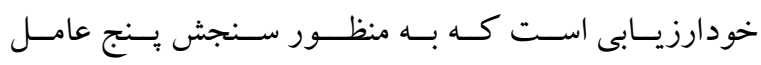

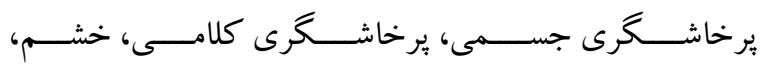

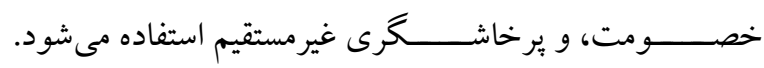

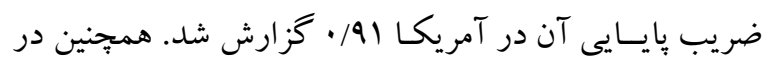

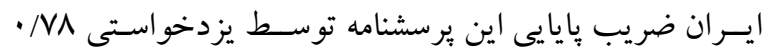

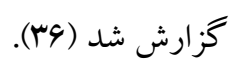

للازم بـه ذكر اسـتـ كـه در اين مطـالعه علـاوه بر مقياس يرخاشخرى از دو روش مشاهده و مصاحبه نيمه ساختاريافته نيز

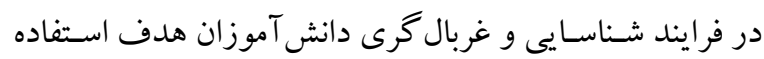

ج) برنـامـه مــداخلـهاى: تدوين اين برنامه براســاس مدل

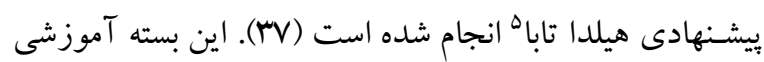
در طى fl جلســ به صـورت هفتهاى دو جلسـه در طى ب ماه بر گزار شـــ. محورهاى كلى اين برنامه شـامل اين موارد بود:

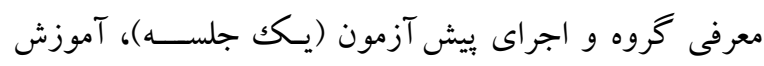

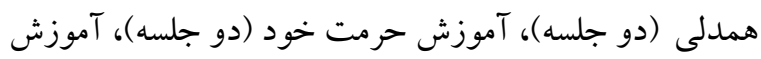

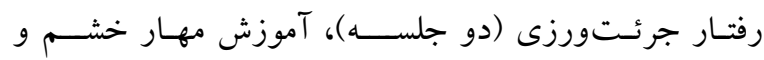
خويشــتندارى ( F جلســه)، دوســت يابى و ارزش هاى دنياى دوسـتانه (دو جلسـه)، تمرين هاى گروهى و اجراى بـ آزمون (يكك جلسـه). اين برنامه مداخلهاى توسـط اسـتادان راهنما و

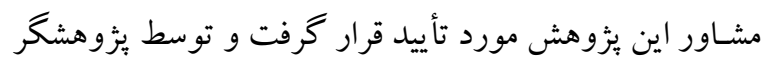

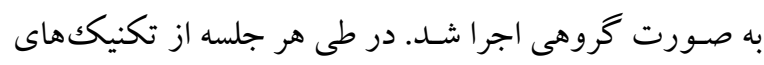

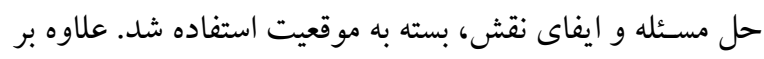

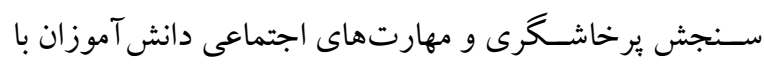

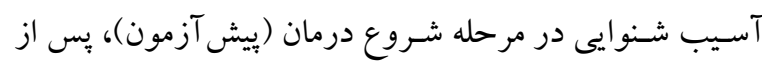
اتمام جلســات نيز براى ســنجش تأثير برنامه مداخله ارزيابى

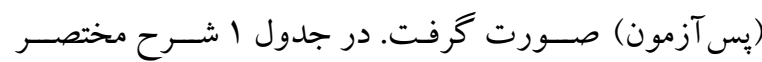
محتو اى جلسات مداخله ارائه شده است.

4. Buss \& Warren

5. Hilda Taba
كه ميانخين سـنى گروه آزمايش و گو اه به ترتيب س If

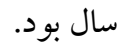
ب) بزار ابز ا. مقياس درجـهبندى مهارت هاى اجتماعى ': در اين بيزوهش إن براى ســنجش مهـارتهــاى اجتمـاعى دانش آموزان از مقيـاس درجهبندى مهارتهاى اجتماعى اســتفاده شـــــ اين مقياس را كرشام و اليوت ب در سال •199 ساختند و داراى سه فرم و الدين، معلمـان، و دانش آموزان اســت و براى ســـهـ دوره تحصــيلى يِيش دبستانى - دبستان، راهنمايى، و دبيرستان طراحى شده است. اين مقيـاس براى كـاربرد در ايران ترجمه شـــده و انطباق يافته اسـت. در بزوهش حساضــر فرم معلم مقيـاس درجـهبنـدى مهارت هاى اجتماعى دوره راهنمايى مورد استفاده قرار كرفت.

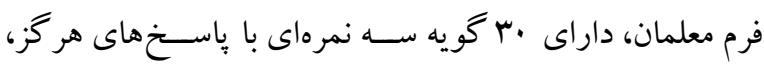
بعضـى اوقات، و بيشــتراوقات اســت. اين مقياس شــامل ســـ خردممقيـاس همكارى (Yا گويسه)، ابراز وجود ( •اكويه)، و

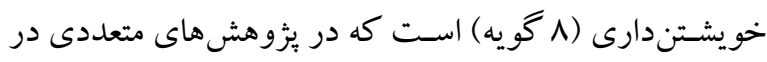
داخل و خارج از كشـور به كار رفته است. يايايى اين برسشنامه توســط گرشـام و اليوت ( •199) با اســفاده از روش آلفاى كرونبـاخ براى نمره كـل مهـارتهـاى اجتمـاعى برابر 94/.

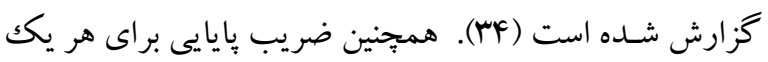

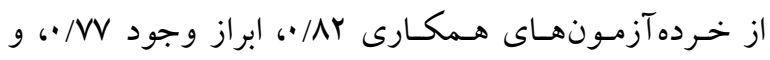
خويشـتن دارى AF/ • به دسـت آمده اسـت. در ايران نيز شـهيم

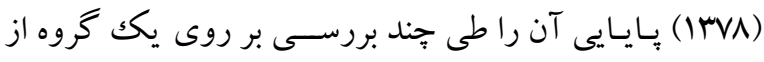

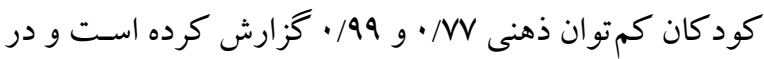
يكك گروه از كود كان بهنجار اين ضرايب از هष/ • تا 9ه/ • براى

فرم هاى معلمان و والدين، متغير بوده است (به نقل از هr).

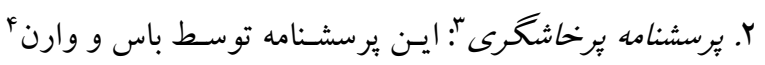

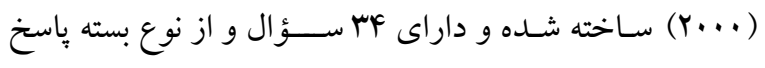
است كه مخصوص سنين 9 تـا M سـال است. يُاسخ سؤ الها از كاملاً مخالفم (1) تا كاملاًُـــــوافقم (ه) درجهبندى شده و وِاسخ

1. Social skills rating scale (SSRS)

2. Gresham \& Elliott

3. Aggression questionnaire (AQ) 
جدول ا: محتواى جلسات مداخله

\begin{tabular}{|c|c|c|}
\hline محتواى هر جلسه & هدف & جلسه \\
\hline 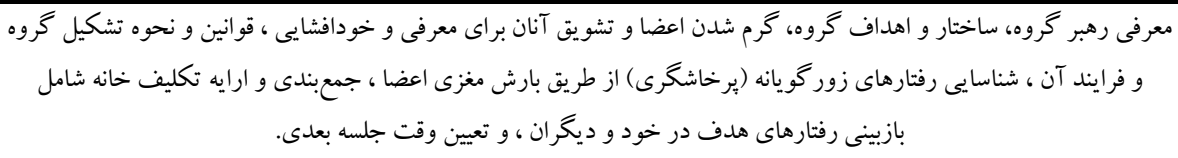 & اجراى بيشى گروه و آزمون & ا جلسه \\
\hline 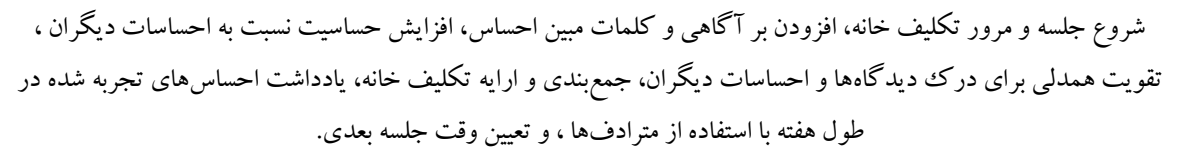 & آموزش همدلى & ب جلسه \\
\hline 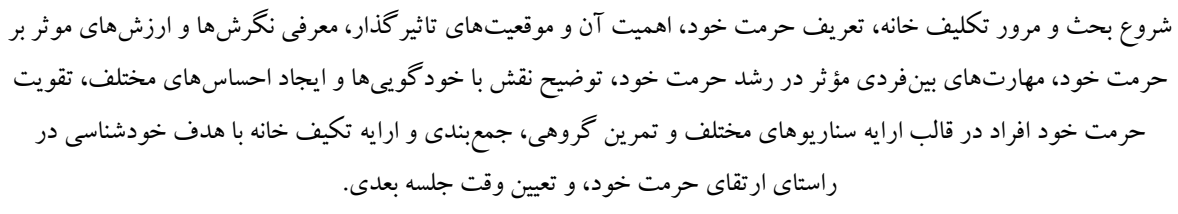 & 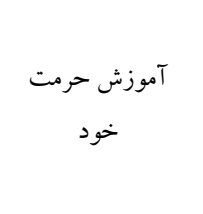 & ب جلسه \\
\hline 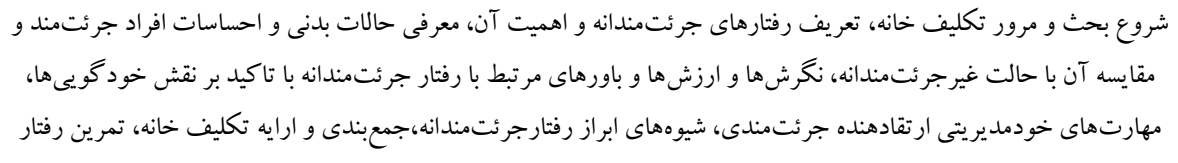 & جرئت آموزش رفتار & ب جلسه \\
\hline 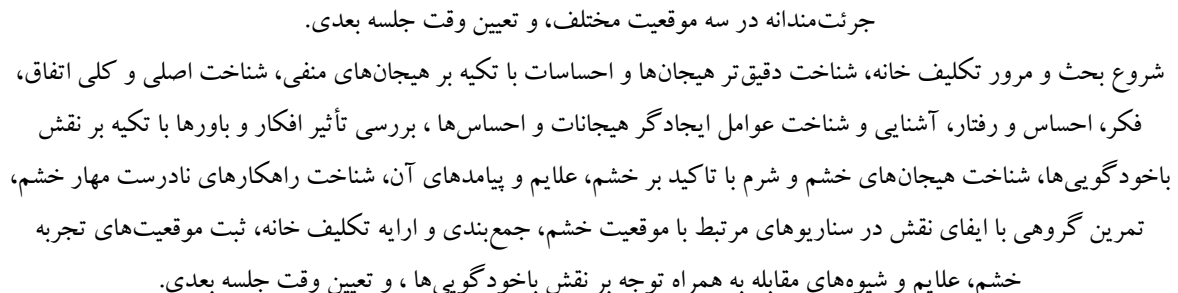 & خويشتندارى (1) آموش خشم و & Y Tلسه \\
\hline 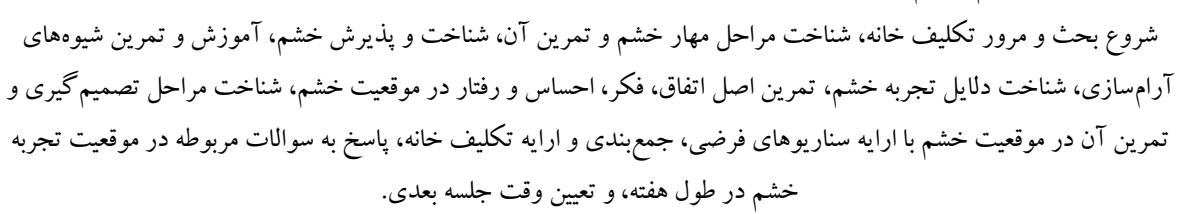 & خو آموزش خشم و & ب جلسه \\
\hline 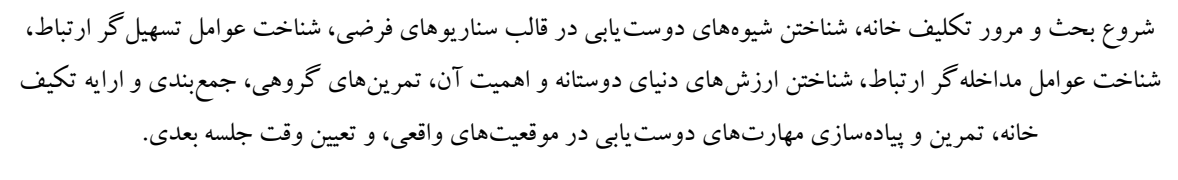 & اروشتهاى دنياى دوسيى و & ب جلسه \\
\hline 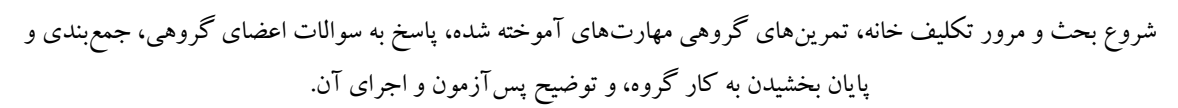 & 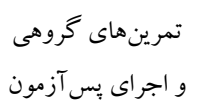 & ا جلسه \\
\hline
\end{tabular}

محرمـانه مورد بررسـى قرار خو اهنـــ گرفتـ. تمـامى مراحل

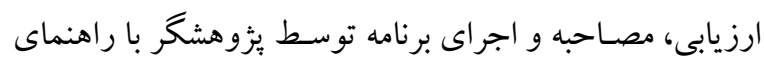

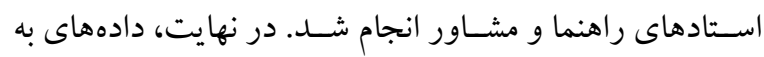

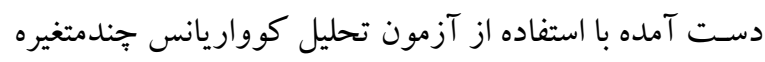
بررسى شد.
روش اجرا بعـد از كســب مجوزهاى للازم با مراجعه به مدرسـهـ باغِهدبان كرج، نمونه مورد مطالعه به صورت در دسترس انتخاب شدند.

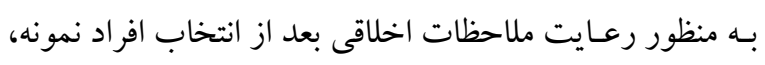

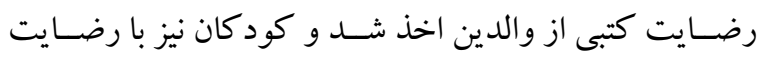

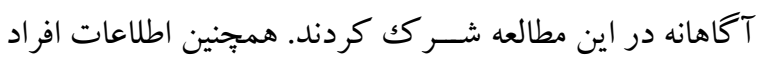

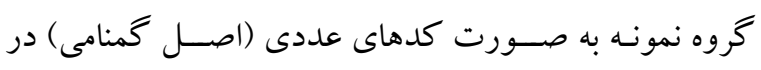

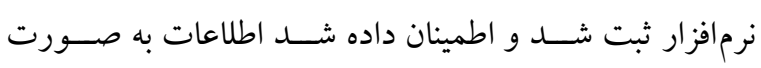


براى مقدار t محاسبه شده ( • • • / / AqV)

يافتهها

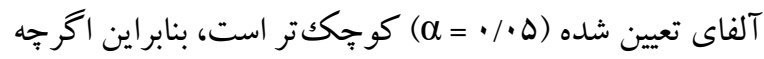

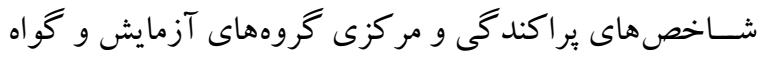

بين ميـانگين دو گروه تفـاوت انسدكى وجود دارد، امـا، اين

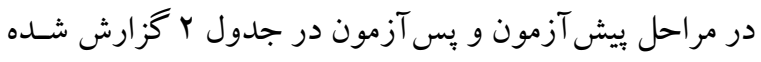

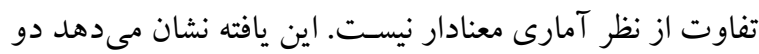

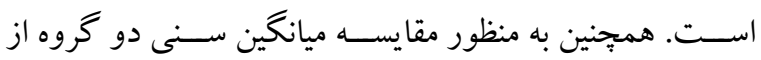
كروه از نظر سنى همتا هستند.

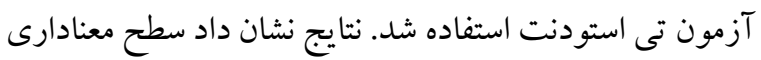

جدول r: شاخصهاى مر كزى و يراكندى دو كروه در متغيرهاى يزوهش

\begin{tabular}{|c|c|c|c|c|c|c|c|c|c|}
\hline \multicolumn{2}{|c|}{ كالمو كروف اسميرنوف } & \multicolumn{2}{|c|}{ يُيَيرى } & \multicolumn{2}{|c|}{ يَ } & \multicolumn{2}{|c|}{ يِيش آزمون } & \multirow{2}{*}{ كروه } & \multirow{2}{*}{ متغير } \\
\hline $\mathbf{P}$ & K-S Z & SD & $\mathbf{M}$ & SD & $\mathbf{M}$ & SD & $\mathbf{M}$ & & \\
\hline.$/ .94$ & $1 / Y F I$ & I/Vr & $r Y / 9$. & $1 / F \Delta$ & Yr/AV & $1 / 9 V$ & $I V / T$. & آزمايش & \multirow{2}{*}{ همكارى } \\
\hline$\cdot / D F Y$ & $\cdot / A \cdot 1$ & - & - & $1 / \Delta$ & MN/Ir & $1 / 4 \wedge$ & $\mathrm{IV} / \cdot \mathrm{V}$ & كواه & \\
\hline.$/ 19 r$ & $1 / \cdot \wedge r$ & 1/מ & $19 / 4$. & $1 / F F$ & $19 / 9 \mathrm{~V}$ & $1 / 19$ & $\mid F / Y$ & آ آزمايش & \multirow{2}{*}{ ابراز وجود } \\
\hline.$/ 1 \cdot 9$ & $1 / r \cdot V$ & - & - & $1 / \wedge \Delta$ & $10 / r$. & $1 / \Delta \Lambda$ & $\mid F / q 4$ & كواه & \\
\hline$\cdot / M r y$ & $\cdot / 9 F F$ & $\cdot / v r$ & $10 / 4$ & $1 / 1 V$ & $10 / 9 \mathrm{~V}$ & $1 / \Delta$ & $\mid r / \Delta r$ & آزمايش & \multirow[b]{2}{*}{ خويشتندارى } \\
\hline$\cdot / 109$ & l/Tro & - & - & $1 / r$ & $11 / 4 \mathrm{~V}$ & $1 / 4 r$ & $\mid r / q r$ & كو اه & \\
\hline$\cdot / T V \Delta$ &.$/ 990$ & $r / \cdot 9$ & $\Delta V / F$ & $1 / \wedge \Delta$ & $\Delta \Lambda / Y$. & r/AF & qr/qr & آايش & \multirow{2}{*}{ مهارت اجتماعى } \\
\hline$\cdot / M$ & $1 / \cdot \wedge V$ & - & - & $\mu / M \Lambda$ & $F F / A$. & $r / V \wedge$ & $k q / q \pi$ & كواه & \\
\hline ./V99 & .1940 & $r / Y q$ & $M / F$. & r/qV & $M / N r$ & $9 / 01$ & $r \mu / F$. & آايش & \multirow{2}{*}{ 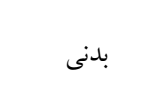 } \\
\hline$\cdot / 9 \wedge \mathrm{V}$ & . MIF & - & - & $r / r \Delta$ & rY/AV & $r / q$. & 19/9r & كواه & \\
\hline .1911 & $\cdot / N \Delta Q$ & $r / Y \Lambda$ & $1 . / N r$ & $r / \Delta V$ & $1 \cdot / r V$ & $r / 94$ & $11 / 4$ & آزمايش & \multirow{2}{*}{ كلامى } \\
\hline • & $1 / F V$ & - & - & $1 / I V$ & $\mid r / 9 V$ & $r / N r$ & $I Y / Y V$ & كواه & \\
\hline$\cdot 10 \cdot 9$ & - /Arr & $1 / 91$ & $1 r / A$. & $1 / 91$ & $1 r / 9 \mathrm{~V}$ & $r / \Delta r$ & 19/Vr & آزمايش & \multirow{2}{*}{ خشم } \\
\hline . &.$/ 91 \mathrm{~V}$ & - & - & $1 / \Delta \Delta$ & r. & $r / r v$ & IN/AV & كو اه & \\
\hline . part & $\cdot / \mathrm{AVT}$ & $1 / \Delta F$ & $10 / 4$. & $1 / \wedge$ & $10 / 14$ & $r / .9$ & rr/Ir & آزمايش & \multirow{2}{*}{ خصومت } \\
\hline . lapt & . NF. & - & - & $r / \cdot 1$ & Tr/MT & r & $r \mid / \Delta r$ & كواه & \\
\hline · /ArI &.$/ 9 Y F$ & $\Delta / \cdot 1$ & $\Delta \Lambda / \Gamma r$ & $\Delta / \Delta r$ & $\Delta V / A$. & $11 / r v$ & $V W / A V$ & آزمايش & \multirow{2}{*}{ يرخاشخرى } \\
\hline$\cdot / q V$ & - /AFV & - & - & $\Delta / q$. & WV/AV & $V / \& \Delta$ & $V Y / 9$. & كواه & \\
\hline
\end{tabular}

نمره بِيايين تر در اين آزمون نشــان دهنده برخاشــرى كمتر

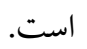

به منظور بررسى اثربخشى برنامه آموزش مديريت شرم بر

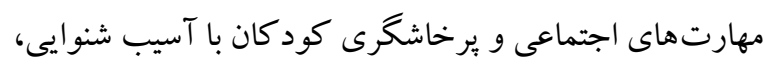

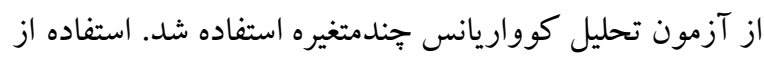

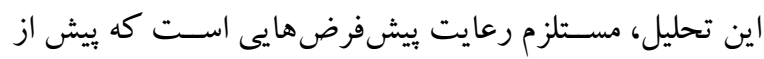

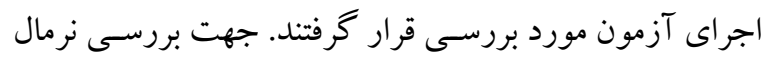
بودن توزيع دادهها، از آزمون كالمو گروف -اسميرنوف استفاده شد (جدول Y). با توجّه به اينكه سطح معنادارى متغيرهاى مورد
بر اســاس اطلـاعـات ارائه شــــه در جـدول ب، در متغير مهارتهـاى اجتمـاعى، بررسـى ميـانگين دو گروه در مرحله بيش آزمون و يس آزمون مؤيد آن است كه نمر ات بِ بس آزمون شر كت كنند كان در گروه آزمايش افزايش داشته است. للازم به أنه ذكر است در اين آزمون كسب نمره بالاتر، نشان دهنده مهارت اجتماعى بيشـتر اسـت. بررسسى ميانخين هاى دو گروه در متغير

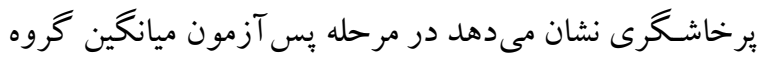
آزمايش در تمامى شــاخصـها كاهش داشــته اسـتـت كه اين

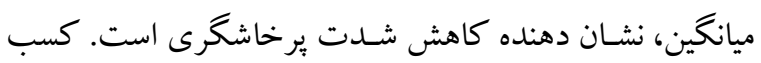


ماتريس كوواريانس متغيرهاى وابسـته در تمام سـطوح متغير

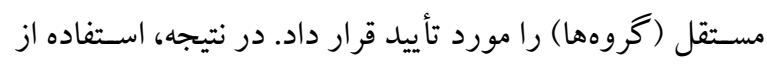

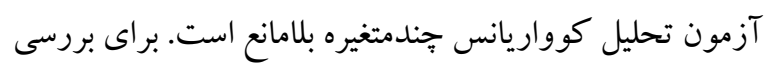

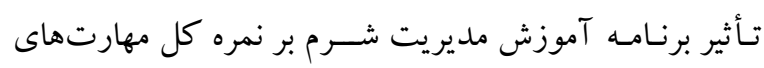

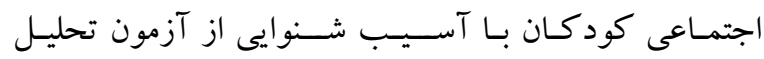

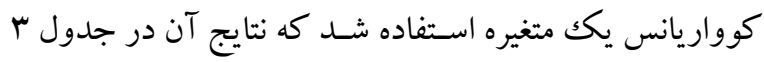
ارائه شده است.
بررسـى در اين آزمون بالاتر از هـ/• به دسـت آمد، مىتوان

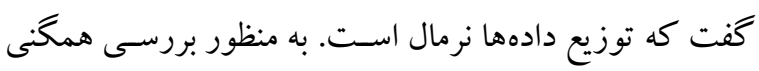

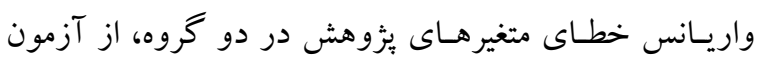

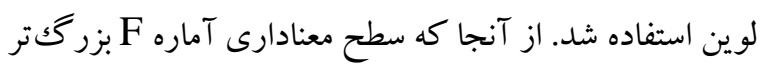

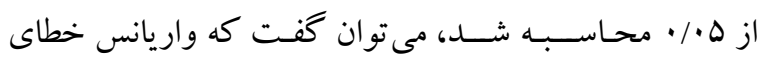
كروهها با همديخر برابر بوده و تفاوتى بين آنها مشـاهده نشــده

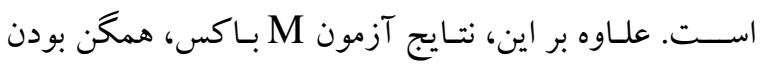

\begin{tabular}{|c|c|c|c|c|c|}
\hline اندازه اثر & سطح معنادارى & Tاره & ميانكين مجذورات & درجه آزادى & منبع \\
\hline \multirow{3}{*}{ - /ADS } & . /YYA & $1 / \Delta r$ & $1 F / 10$ & 1 & يَيش آزمون \\
\hline & $\cdot \ldots$ * & $19 \cdot / \Delta F$ & $\mid F q T / \Delta V$ & 1 & كروه \\
\hline & - & - & $9 / \Gamma$. & rV & خطا \\
\hline
\end{tabular}

مى توان كفت كه برنامه آموزش مديريت شرم موجب افزايش

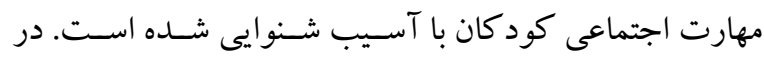

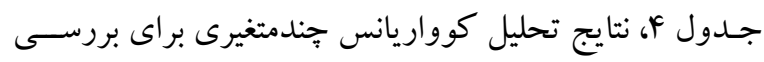

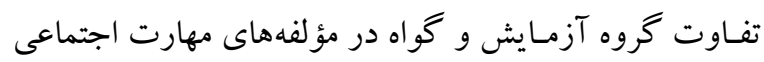

كز ارش شده است.
بـا توجسه بـه جـدول ب آمـاره F مهـارت اجتمـاعى در

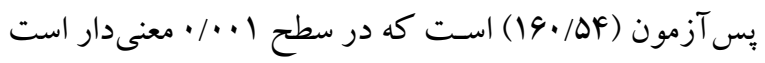

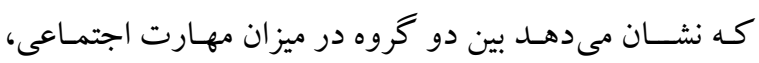

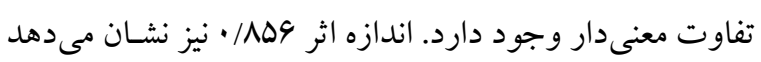

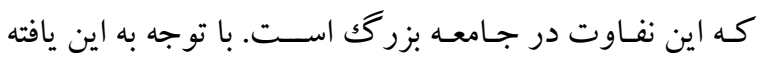

جدول ع: نتايج تحليل كوواريانس جندمتغيرى براى بررسى تفاوت كروه آزمايش و كواه در مؤلفههاى مهارت اجتماعى

\begin{tabular}{|c|c|c|c|c|c|c|}
\hline اندازه اثر & سطح معنادارى & Tاره F & ميانكين مجذورات & درجه آزادى & منبع & متغير \\
\hline \multirow{3}{*}{ - MFF } & .1941 &.$/ 199$ & $\cdot \pi V r$ & 1 & ييش آزمون & \multirow{3}{*}{ همكارى } \\
\hline &.$/ \ldots * *$ & $V Y / 91$ & $109 / 9 V$ & 1 & كروه & \\
\hline & - & - & $r / 19$ & ro & خطا & \\
\hline \multirow{3}{*}{$.190 \mathrm{~V}$} & . / $4 a r$ & - /FAV & $1 / 41$ & 1 & يُش آزمون & \multirow{3}{*}{ 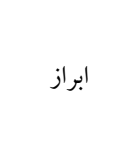 } \\
\hline & $\cdot / \ldots$ *** & $F V / A q$ & $1 \% N / 99$ & 1 & كروه & \\
\hline & - & - & $r / q$. & ro & خطا & \\
\hline \multirow{3}{*}{ - /VAS } & - / Far & $\cdot / \Delta \wedge \mu$ & $1 / .9$ & 1 & يِيش آزمون & \multirow{3}{*}{ خو يشتندارى } \\
\hline & $\cdot /{ }^{* * * *}$ & $91 / V Y$ & IVI/TY & 1 & كروه & \\
\hline & - & - & $1 / 19$ & ro & خطا & \\
\hline
\end{tabular}

نظر مؤلفـههاى مهارت اجتماعى، تفاوت معنى دار وجود دارد.

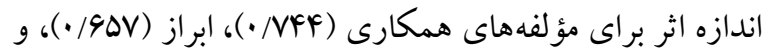
خويشــتندارى (VAS/•) نيز نشــان مىدهد كه اين نفاوت در جـامعـه بزرك اســت. بـا توجـه به اين يافته مى توان كفت كه

$$
\begin{aligned}
& \text { بـا توجسه بسه جـدول F آمساره F مهـارت اجتمـاعى در } \\
& \text { يسس آزمـون بـراى مـؤلـفـههـاى هـمـكـارى، ابـرازگرىى، و } \\
& \text { خويشـتندارى به ترتيب 91VY، و و PV/A9 }
\end{aligned}
$$

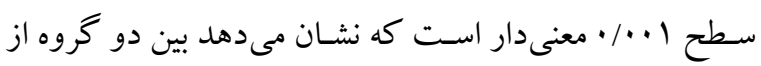


تككتغيرى استفاده شد كه نتايج آن در جدول ه گزارش شده

است. - n
برنامه آموزش مديريت شرم موجب افزايش مؤلفههاى مهارت اجتماعى كود كان با آسيب شنو ايى مى مورد.

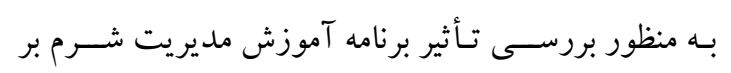

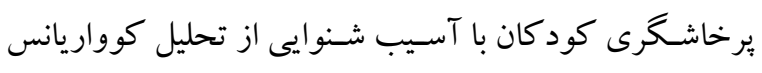

\begin{tabular}{|c|c|c|c|c|c|c|}
\hline اندازه اثر & سطح معنادارى & F Tاره & ميانغين مجذورات & درجه آزادى & منبع & متغير \\
\hline & $\cdot / / 999$ & $1 / / 4$ & $F V / V$ & 1 & ي ييش آزمون & \\
\hline \multirow[t]{2}{*}{$\cdot / v \cdot v$} & $\cdot \ldots{ }^{* * *}$ & $90 / 19$ & $r V F \cdot / r r$ & 1 & 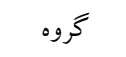 & إيرخاشخرى \\
\hline & - & - & $k Y / \cdot r$ & TV & خطا & \\
\hline
\end{tabular}

برنـامـه آموزش مـديريت شــرم موجب كاهش برخاشـــرى

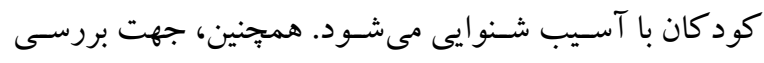

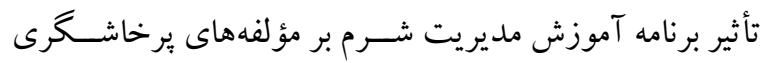

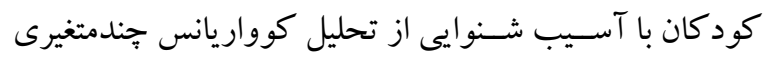
استفاده شد كه نتايج آن در جدول 9 ارائه شده است.
بـا توجـه بـه نتـايج جـدول ه، آمـاره F برخـاشــرى در

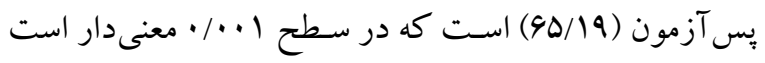

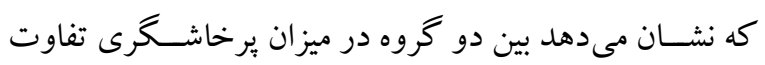

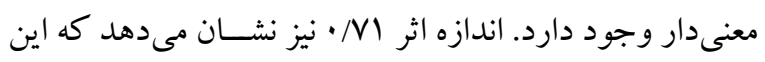

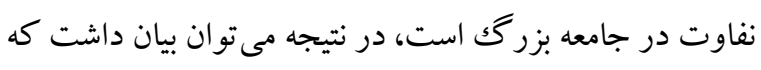




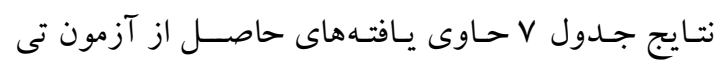
همبسـته (وابسـته) جهت مقايسـه نمرات مرحله بيش آزمون و

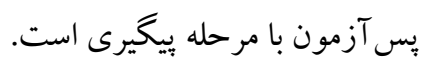

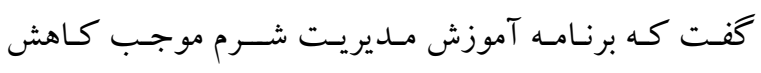

مؤلفههاى برخاشخرى كود كان با آسيب شنوايى مىشود.

\begin{tabular}{|c|c|c|c|c|c|c|}
\hline \multicolumn{3}{|c|}{ يس آزمون } & \multicolumn{3}{|c|}{ ييش آزمون } & \multirow{2}{*}{ متغيرها } \\
\hline Sig. & df & $t$ & $\begin{array}{l}\text { Sig. } \\
\end{array}$ & df & $t$ & \\
\hline . TIV & if & $1 /$ rar & $\cdot{ }^{\prime} \ldots{ }^{\infty}$ & 18 & V/AFI & همكارى \\
\hline . & If & 1 & $\cdot \ldots *$ & If & $9 / 191$ & ابراز وجود \\
\hline . & if & $\cdot / M M$ & $\cdot \ldots *$ & If & $V / 911$ & خويشتندارى \\
\hline$\cdot / 1.4$ & if & $1 / N \cdot 4$ & 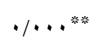 & if & $|r / N|$. & مهارت اجتماعى \\
\hline.$/ 11$ & if & $1 / N \cdot 0$ & $\cdot / r r^{\infty}$ & if & $r / \Delta V I$ & يرخاشخرى كلامى \\
\hline תr & If & $\cdot / A \cdot V$ & $\cdot \ldots{ }^{\infty}$ & if & $\Delta / r \cdot r$ & خشم \\
\hline.$/ 194$ & if & $1 / 491$ & 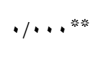 & if & $1 \pi / \mu \cdot 4$ & خصومت \\
\hline$\cdot / r \Delta S$ & if & $1 / 199$ &.$/ \ldots \infty$ & if & $\Delta / \cdot V r$ & يرخاشكرى \\
\hline
\end{tabular}

$\mathrm{P}<\cdot / \cdot \Delta^{*} \mathrm{P}<\cdot / \cdot 1^{* * *}$

رايف و ميروم ترووت (YI) و احمد (Yr) همسـو و همخوان است.

نتايج يزوهش حاضــر مبنى بر مهار برخاشـــرى از طريق

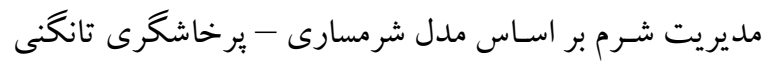
(19) قابل تبيين اسـت. در اين مدل بر نقش و اهميت هيجانها تأكيد مىشـود و هيجان محور شـرم اسـت كه به واسـطه آن،

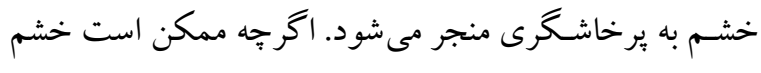

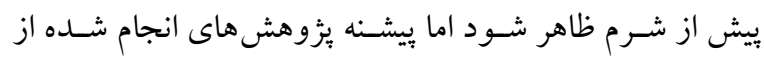

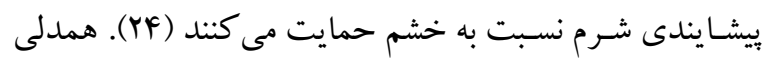

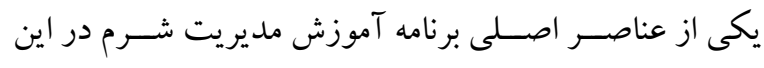

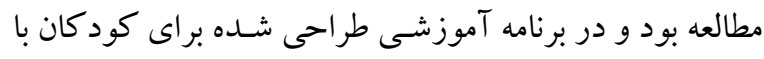

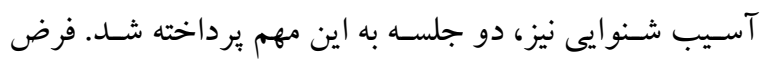

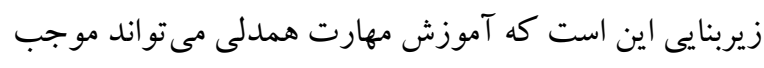

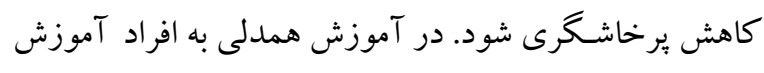

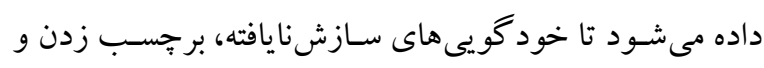

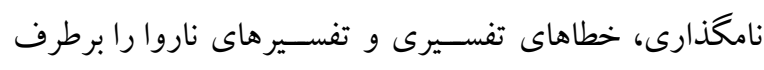

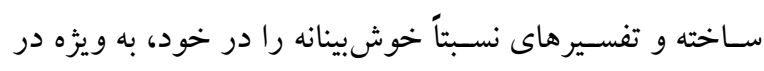
هنگام قرار كرفتن در موقعيتهاى مختلف آسيبزا، جايكزين
طبق نتايج به دسـت آمده، سطوح معنادارى مقدار t نشـان مىدهــ نمرات گرووه آزمـايش در دو مرحلـه ييش آزمون و

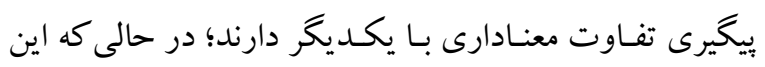

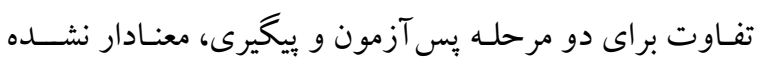

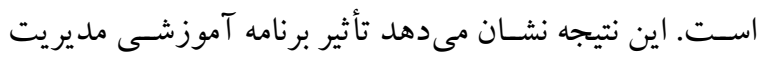

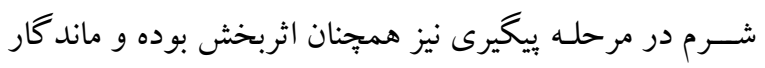

\section{بحث و نتيجه كيرى}

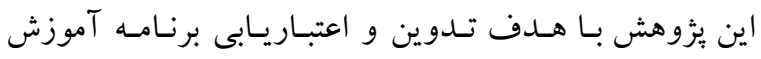
مديريت شـرم بر برخاشخرى و مهارت هاى اجتماعى كود كان

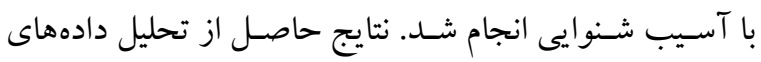
يثزوهش نشـان داد برنامه آموزش مديريت شـرم تأثير معنادارى لئي بر كاهش يرخاشـخرى و مؤلفه هاى كلامى، خشـم و خصومت آن در كود كان با آسيب شنوايى دارد اما بر اساس نتايج همين

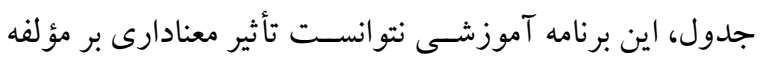

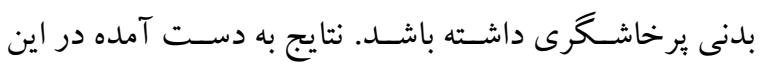
مطـالعه با نتايج يزوهشهاى احمد (IV)، اليسـون و همكاران

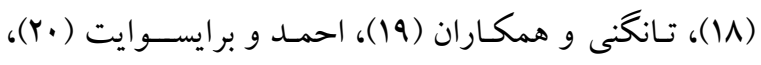


آكاهى افر اد نسـبت به خشـم، و آموزش شيوهها و راهبردهاى

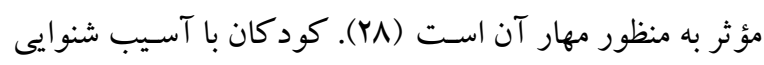

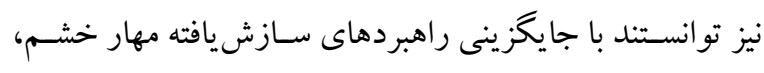

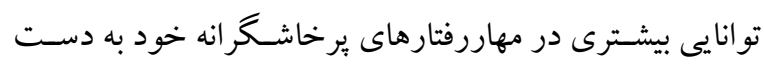

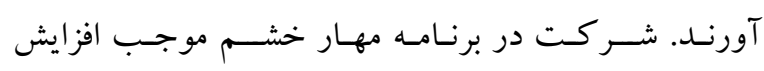

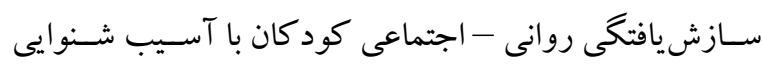

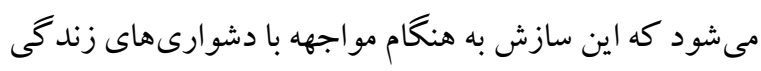

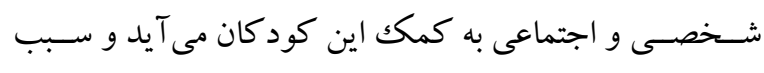

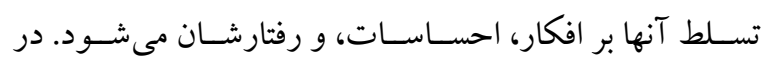

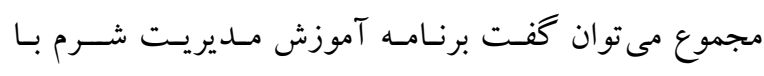

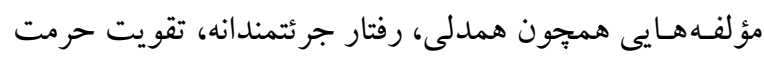

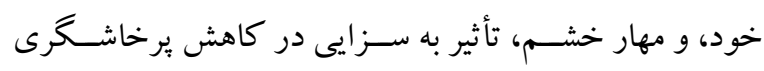
كود كان با آسـيب شـنوايى داشته است. علاوه بر اين، به منظور بررسى تأثير آموزش مديريت شرم بر بهبود مؤلفه لهاى مهارت

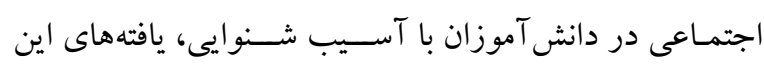
يُوهش نشان داد كه اجر اى برنامه آموزش مديريت شرم تأثير

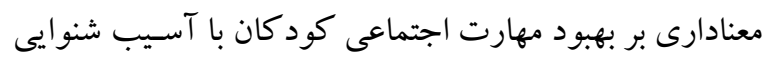

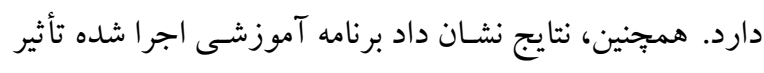

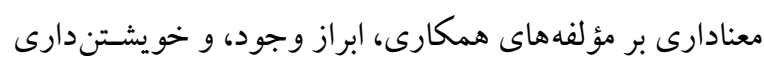
داشـته است. در تبيين اثربخشى برنامه آموزش مديريت شرم بر موري

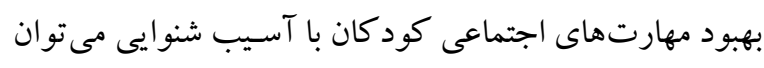

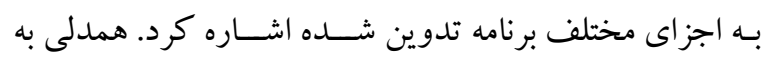

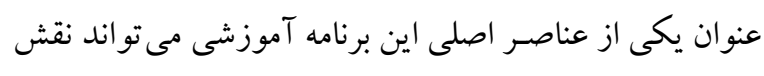

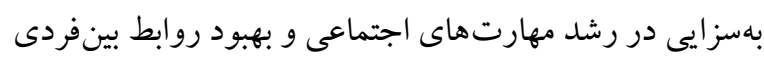

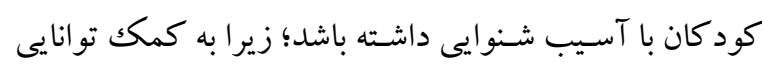

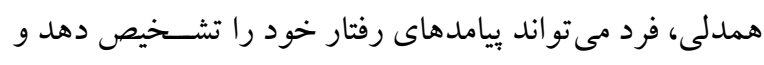

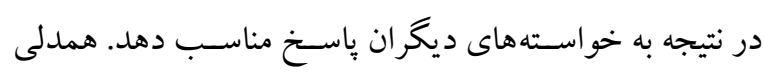

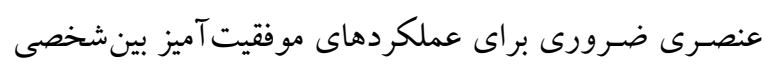

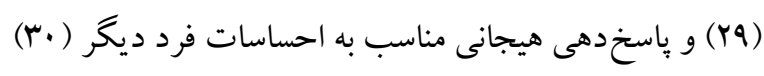

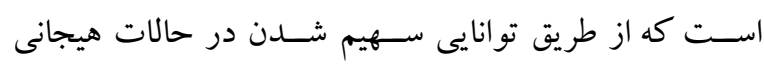

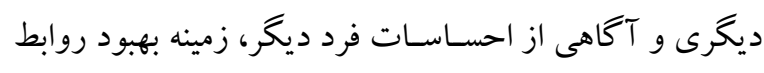
اجتماعى را فراهم مى سـازد و فرد را با محيط اجتماعى بيوند
سـازند. در جريان درمان، مراجعين تشـويق مىشـوند تا افكار

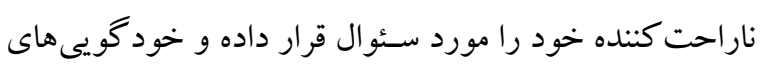

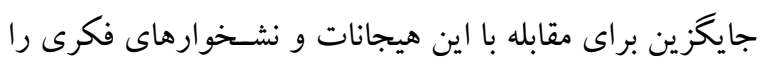

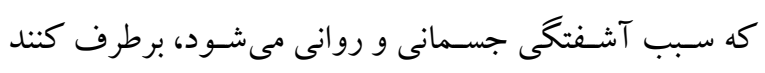

يـافتههاى اين يزوهش مؤيد آن اســت كنجاندن آموزش

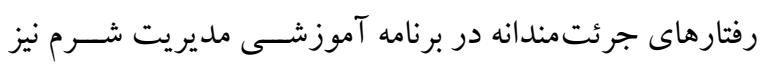

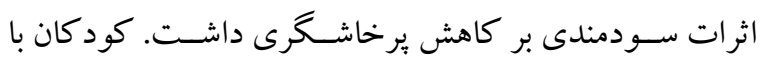

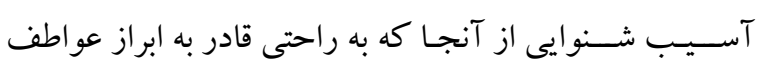

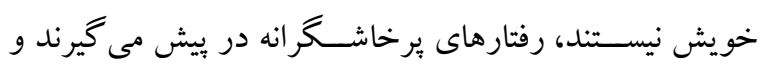

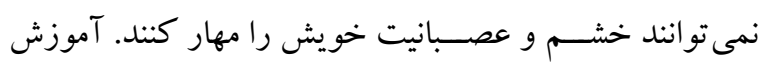

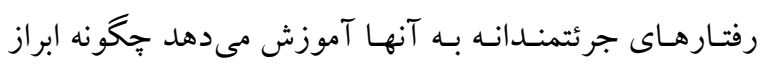

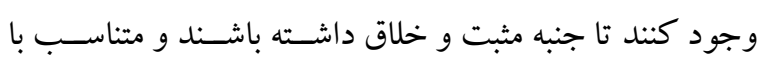

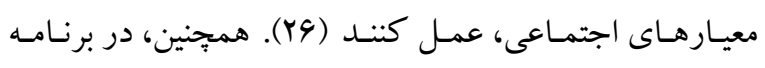
آموزش مديريت شرم، تقويت حرمت خود نيز مورد توجه قرار

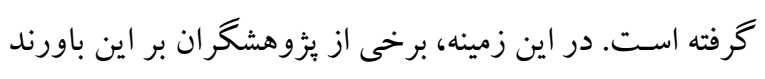

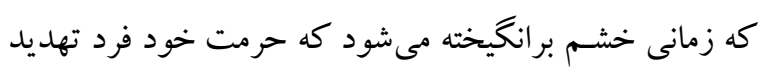

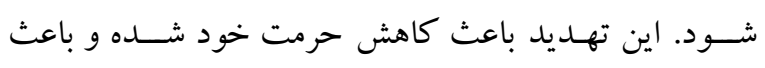
مى شود كه اين احساس به ظهور عواطف منفى منجر شود و در

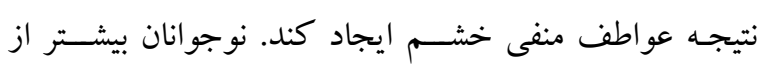

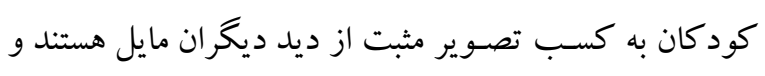

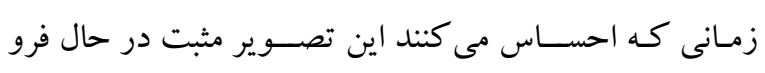

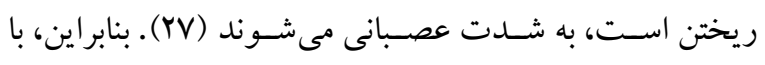

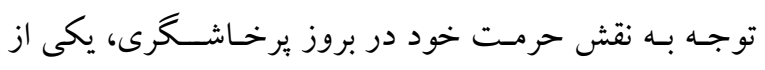

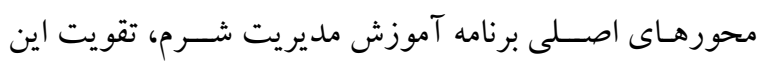

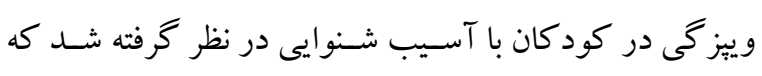
سودمندى آن در نتايج به دست آمده قابل مشاهده است.

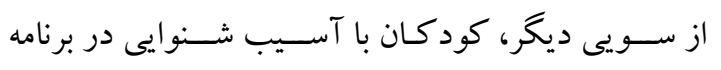
آموزش مـديريت شــرم، مهارت مهار خشـــم را نيز آموختند. هدف از درمانها و مداخلات مهار خشـم، كاهش احسـاسـات

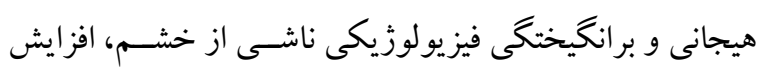


اثربخش بودن برنامه آموزشسى مديريت شـرم بر برخاشــرى

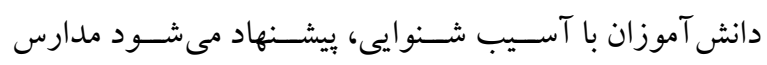

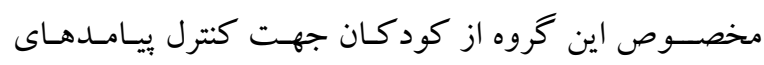

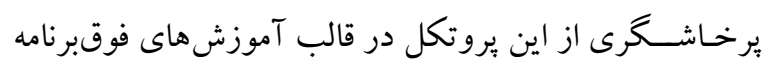

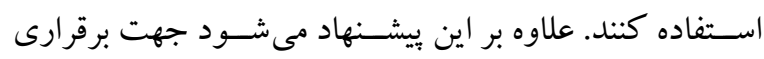
ارتباط كود كان با آسـيب شـنو ايى با دنياى اجتماعى يير امون،

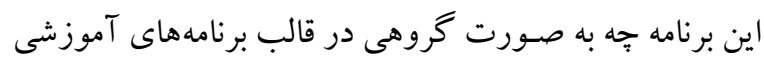

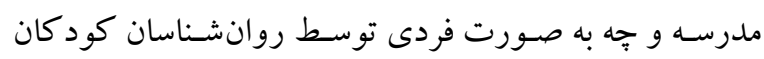
استثنايى مورد توجه قرار گيرد. تشـكر و قدردانى : اين بثزوهش بر كرفته از رسـاله دكتراى آقاى

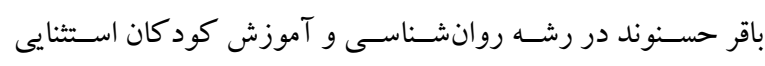

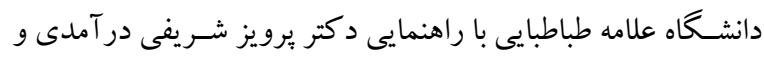

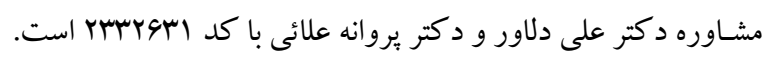

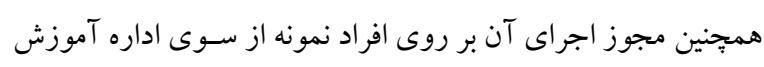

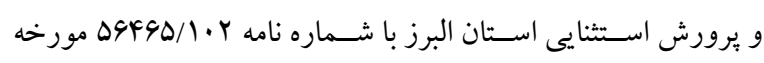

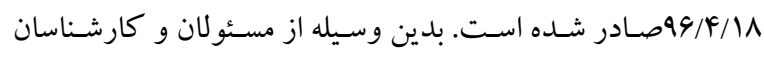

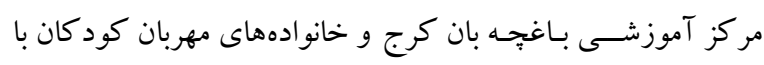

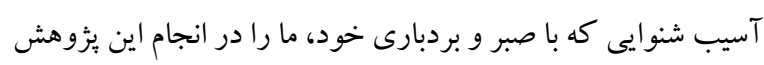
يارى كردند، صمميمانه تشكر مىشود.

تضــاد منافع: اين يزوهش بدون حمايت مالى ســازمان خاصسى

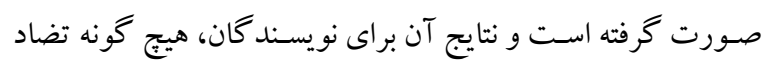

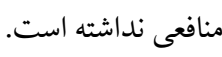

مىزند و از وارد كردن آسيب به افراد ديگر جلو گيرى مى كند

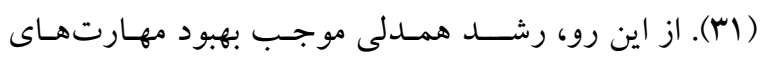

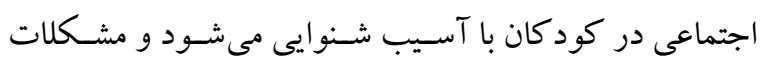
مربوط به روابط بينشخصى رد را كاهش مى دهد. علاوه بر اين،

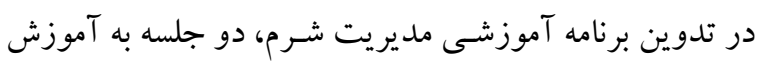

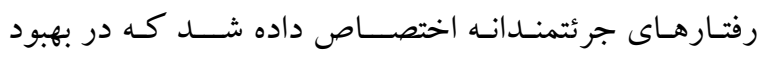
مهارتهاى اجتماعى كود كان با آسيب شـنوايى سـهيم است.

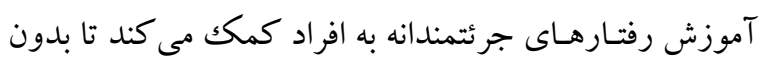
آسيب به ديخر ان، مهارتهايى در زمينه ابراز حقوقشان كسب رنب كنتــ. افراد بِ از آموزش رفتـارهـاى جرئت مندانه، نخخرش

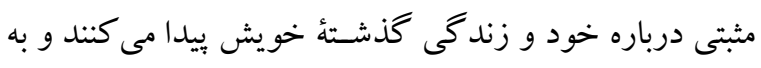

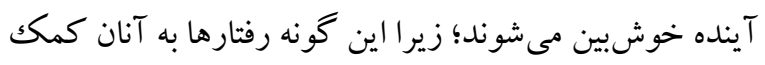

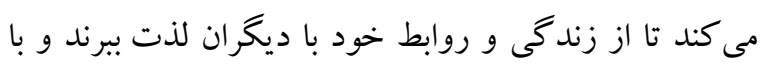

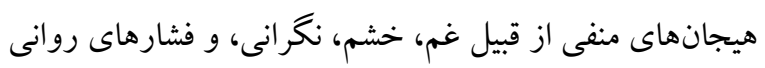
به كونهاى سازش يافته مقابله كنند (Tr).

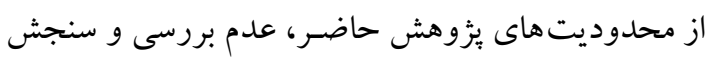

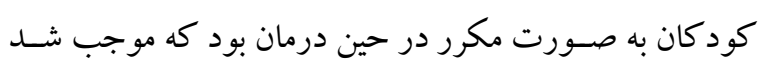

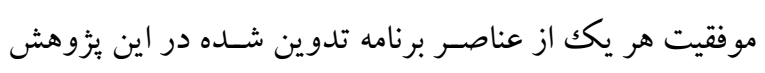

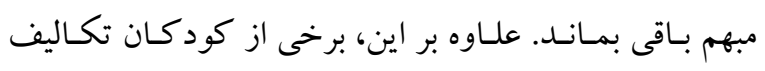

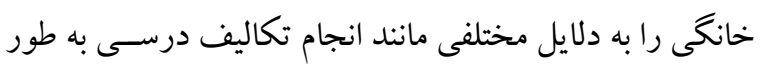

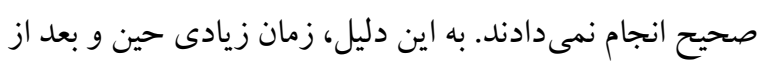
اتمام جلســات گروهى صـرف تشـويق اين افراد جهت انجام

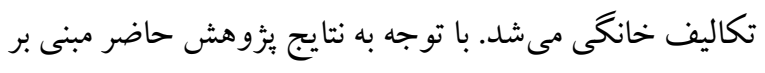




\section{References}

1. Fellinger J, Holzinger D. Enhancing resilience to mental health disorders in deaf school children. In: Zand DH, Pierce KJ, editors. Resilience in deaf children: adaptation through emerging adulthood. New York, NY: Springer; 2011, PP: 169-205. [Link]

2. Adachi PJC, Willoughby T. The effect of violent video games on aggression: Is it more than just the violence? Aggress Violent Behav. 2011; 16(1): 55-62. [Link]

3. Stuewig J, Tangney JP, Heigel C, Harty L, McCloskey L. Shaming, blaming, and maiming: Functional links among the moral emotions, externalization of blame, and aggression. J Res Pers. 2010; 44(1): 91102. [Link]

4. Tangney JP, Stuewig J, Mashek D, Hastings M. Assessing jail inmates' proneness to shame and guilt: Feeling bad about the behavior or the self? Crim Justice Behav. 2011; 38(7): 710-734. [Link]

5. Martin FN, Greer J. Introduction to audiology (with CD-ROM). 9th Edition. Needham Heights, MA, USA: Allyn \& Bacon, Inc; 2005. [Link]

6. Littrell KH, Littrell SH. Current understanding of violence and aggression: assessment and treatment. J Psychosoc Nurs Ment Health Serv. 1998; 36(12): 18-24. [Link]

7. Yurtal F, Artut K. An investigation of school violence through Turkish children's drawings. J Interpers Violence. 2010; 25(1): 50-62. [Link]

8. Barker DH, Quittner AL, Fink NE, Eisenberg LS, Tobey EA, Niparko JK, et al. Predicting behavior problems in deaf and hearing children: The influences of language, attention, and parent-child communication. Dev Psychopathol. 2009; 21(2): 373-392. [Link]

9. Connolly J, Nocentini A, Menesini E, Pepler D, Craig W, Williams TS. Adolescent dating aggression in Canada and Italy: A cross-national comparison. Int J Behav Dev. 2010; 34(2): 98-105. [Link]

10. Mathews ES. Towards an independent future: Life skills training and vulnerable deaf adults. Irish Journal of Applied Social Studies. 2015; 15(1): 1. [Link]

11. Laugen NJ, Jacobsen KH, Rieffe C, Wichstrøm L. Social skills in preschool children with unilateral and mild bilateral hearing loss. Deafness Educ Int. 2017; 19(2): 54-62. [Link]

12. Ferguson CJ, San Miguel C, Kilburn Jr. JC, Sanchez P. The effectiveness of school-based anti-bullying programs: A meta-analytic review. Crim Justice Rev. 2007; 32(4): 401-414. [Link]

13. Herring S, Gray K, Taffe J, Tonge B, Sweeney D, Einfeld S. Behaviour and emotional problems in toddlers with pervasive developmental disorders and developmental delay: associations with parental mental health and family functioning. J Intellect Disabil Res. 2006; 50(Pt 12): 874-882. [Link]

14. Del Rosario PM, White RM. The internalized shame scale: temporal stability, internal consistency, and principal components analysis. Pers Individ Dif. 2006; 41(1): 95-103. [Link]

15. Newgent RA, Behrend BA, Lounsbery KL, Higgins KK, Lo WJ. Psychosocial educational groups for students (PEGS) an evaluation of the treatment effectiveness of a school-based behavioral intervention program. Counseling Outcome Research and Evaluation. 2010; 1(2): 80-94. [Link]

16. Patchin JW, Hinduja S. Traditional and nontraditional bullying among youth: A test of general strain theory. Youth Soc. 2011; 43(2): 727-751. [Link]

17. Ahmed E. Understanding bullying from a shame management perspective: Findings from a three-year follow-up study. Educational and Child Psychology. 2006; 23(2): 25-39. [Link]

18. Elison J, Garofalo C, Velotti P. Shame and aggression: theoretical considerations. Aggress Violent Behav. 2014; 19(4): 447-453. [Link]

19. Tangney JP, Wagner P, Fletcher C, Gramzow R. Shamed into anger? The relation of shame and guilt to anger and self-reported aggression. J Pers Soc Psychol. 1992; 62(4): 669-675. [Link]

20. Ahmed E, Braithwaite V. What, me ashamed?" shame management and school bullying. J Res Crime Delinq. 2004; 41(3): 269-294. [Link]

21. Rieffe CJ, Meerum Terwogt M. Anger communication in deaf children. Cogn Emot. 2006; 20: 12611273. [Link]

22. Ahmed E. Pastoral care to regulate school bullying: shame management among bystanders. Pastor Care Educ. 2005; 23(2): 23-29. [Link] 
23. Brown M, Bergen D. Play and social interaction of children with disabilities at learning/activity centers in an inclusive preschool. J Res Child Educ. 2002; 17(1): 26-37. [Link]

24. Covert MV. Moderators of the effects of experimentally induced shame on indirect aggression [Doctoral dissertation]. [Virginia, USA]: George Mason University; 2004. [Link]

25. Aldao A, Nolen-Hoeksema S, Schweizer S. Emotion-regulation strategies across psychopathology: A meta-analytic review. Clin Psychol Rev. 2010; 30(2): 217-237. [Link]

26. Khazaie F, Shairi MR, Heidari-Nasab L, Jalali MR. Comparison of self-efficacy, self-esteem, social anxiety, shyness and aggression among high school students with different levels of assertiveness. Journal of Kashan University of Medical Sciences (FEYZ). 2014; 18(3): 229-238. [Persian]. [Link]

27. Lapsley DK, Aalsma MC. An empirical typology of narcissism and mental health in late adolescence. J Adolesc. 2006; 29(1): 53-71. [Link]

28. Sedaghat $\mathrm{S}$, Moradi $\mathrm{O}$, Ahmadian $\mathrm{H}$. The effectiveness of anger cognitive behavioral group training on aggression of third grade aggressive female students in Baneh's high schools. Medical Sciences. 2015; 24(4): 215-220. [Persian]. [Link]

29. de Sousa A, McDonald S, Rushby J, Li S, Dimoska A, James C. Understanding deficits in empathy after traumatic brain injury: the role of affective responsivity. Cortex. 2011; 47(5): 526-535. [Link]

30. de Wied M, van Boxtel A, Zaalberg R, Goudena PP, Matthys W. Facial EMG responses to dynamic emotional facial expressions in boys with disruptive behavior disorders. J Psychiatr Res. 2006; 40(2): 112-121. [Link]

31. Brown RP, Zeigler-Hill V. Narcissism and the non-equivalence of self-esteem measures: A matter of dominance? J Res Pers. 2004; 38(6): 585-592. [Link]

32. Hosseinkhanzadeh AA, Rahimi E, Ostavi E. The effectiveness of assertiveness skills training in improving self- esteem and peer relationships of slow learner students. Psychology of Exceptional Individuals. 2016; 6(21): 1-22. [Persian]. [Link]

33. Ahmed E, Braithwaite J. Forgiveness, shaming, shame and bullying. Aust N Z J Criminol. 2005; 38(3): 298-323. [Link]

34. Shahim S. Study of social skills in a group of blind students in terms of teachers. Journal of Psychology and Education. 2002; 32(1): 121-139. [Persian]. [Link]

35. Asadi Gandomani R, Pezeshk S, Hashemi Azar Z, Sarami G. Investigation of relationship between social skills and behavioral problems in student with mild intellectual disability. Middle Eastern Journal of Disability Studies. 2015; 5: 22-28. [Persian]. [Link]

36. Heshmati A, Yazdkhasti F, Molavi H. The relationship between temperament and perceived parental acceptance-rejection and aggressive behaviors in deaf and hearing students in Isfahan. Journal of Research in Cognitive and Behavioral Sciences. 2012; 2(1): 27-42. [Persian]. [Link]

37. Nyström MB, Mikkelsen F. Psychopathy-related personality traits and shame management strategies in adolescents. J Interpers Violence. 2013; 28(3): 519-537. [Link] 